\title{
УДК 62.515
}

\author{
П.П. Ткачук, Ю.І. Бударецький, Ю.В. Щавінський, В.В. Прокопенко \\ Академія сухопутних військ імені гетьмана Петра Сагайдачного, Львів
}

\section{ВПЛИВ ЗАСОБІВ АВТОМАТИЗАЦІЇ УПРАВЛІННЯ ПІДРОЗДІЛАМИ І ВОГНЕМ АРТИЛЕРІЇ НА ЕФЕКТИВНІСТЬ П̈Ї ЗАСТОСУВАННЯ}

\begin{abstract}
Запропонована стаття є спробою аналізу найбільш важливих факторів, які впливають на точність $i$ своєчасність відкриття вогню артилерійських систем. В сучасних збройних конфліктах иее обумовлюється потребою негайного ураження об'єктів $і$ иілей з високою точністю. В статті розглянуто вплив засобів автоматизаиї на точність і оперативність підготовки даних для стрільби. Запропоновано иляхи програмноапаратної побудови засобів автоматизачії, які сприяють подальшому розвитку автоматизованої системи управління вогнем і артилерійськими підрозділами та створення на ї̈ основі розвідувально-вогневих і розвідувально-ударних комплексів.
\end{abstract}

Ключові слова: автоматизована система управління, АСУВ, комплекс засобів автоматизачії, КЗА, ефективність вогню артилерійських систем, точність підготовки даних для стрільби.

\section{Постановка проблеми}

Причіпні артилерійські системи (АС) і самохідні артилерійські установки (САУ), реактивні системи залпового вогню (РСЗВ) сьогодні не тільки знаходяться на озброєнні підрозділів збройних сил передових у військовому відношенні країн, але й використовуються незаконними збройними формуваннями (НЗФ) на території України під прикриттям густонаселених районів [6]. Перебування їх на вогневій позиції протягом обмеженого часу потребує негайного визначення координат, передачі і підготовки даних для стрільби та відкриття вогню у відповідь. Необхідність ведення контрбатарейної (контргарматної) боротьби і в той же час відсутність на озброєнні у вітчизняних артилерійських підрозділах працюючих електронно-обчислювальних машин і апаратури прийому-передачі даних, цифрових засобів зв'язку потребує негайного теоретичного обгрунтування і практичної розробки комплексу засобів автоматизації та поєднання їх в майбутньому в автоматизовану систему управління підрозділами i вогнем артилерії.

\section{Аналіз останніх досліджень}

Провідні країни світу давно прийняли на озброєння автоматизовані системи управління вогнем (АСУВ) артилерії: США - «ТАCFIRE» (Tactical Fire Direction Syslem), AFATDS (Advanced Field Artillery Tactical Data System); Німеччина - ADLER (Artillerie Daten Lage und Einsatz Rechnerverbund); Російська Федерація (РФ) - АСУ "Капустник-Б" $з$ автоматизованою системою управління наведенням і вогнем (АСУНВ) «Успех». На думку зарубіжних військових фахівців, введення системи управління «AFATDS» рівноцінно заміні 2500 АC M109A6.
На сьогодні відсутність в артилерійських підрозділах ЗС України сучасних засобів розвідки, зв'язку і АСУВ не дозволяє вітчизняній артилерії реалізувати $50 \%$ iї можливостей. Разом з тим на озброєнні підрозділів знаходяться застарілі машини управління, радіоелектронні засоби та обчислювальна техніка яких виконана на елементній базі 70-х, 80-х років минулого століття. Тому рівень вітчизняних засобів автоматизації підготовки даних для стрільби значно відстає від відповідних засобів, що використовуються в провідних арміях світу. Таким чином, сьогодні актуальним напрямом є розробка вітчизняної АСУВ артилерійських підрозділів.

\section{Мета статті}

Зробити аналіз впливу процесу автоматизації підготовки даних для стрільби та управління вогнем артилерійськими підрозділами на ефективність застосування артилерії.

\section{Виклад основного матеріалу}

Відповідно до Бойового статугу Сухопугних військ засоби управління підрозділами і вогнем включають в себе засоби зв'язку, засоби автоматизації управління, технічні засоби прихованого управління військами, засоби обробки інформації [1]. При цьому засоби зв'язку включають обладнання (технічні засоби) для обміну інформацією в системі управління військами. Для забезпечення управління застосовуються радіо, проводові і сигнальні засоби зв'язку. Радіозасоби є найважливішими, а іноді єдиними засобами забезпечення управління підрозділами. Під час виконання поставленого завдання всі команди по радіо передаються відкритим текстом або з використанням переговорних таблиць i апаратури 3АЗ, при цьому найменування підрозділів 
і посади командирів вказуються позивними, а пункти місцевості - відносно орієнтирів, а також умовними (кодованими) найменуваннями.

Засоби автоматизації управління призначені для підвищення ефективності управління підрозділами (оперативності, надійності та якості управління) 3 метою найбільш повного використання їх бойових можливостей. Вони повинні забезпечувати: інформаційний обмін між командно-спостережним пунктом підрозділу і вищими пунктами управління; автоматизацію передачі сигналів і команд управління, взаємодії й оповіщення; скорочення часу збору, обробки і передачі даних обстановки; підготовку даних для затвердження рішення і планування дій; відображення i документування інформації.

Засоби автоматизованого управління дивізіоном (батареєю) згідно з Бойовим статутом артилерії частина 2 розміщуються в командирських та командноштабних машинах і призначені для підвищення стійкості, безперервності, оперативності і скритності управління підрозділами та вогнем [2].

Засоби обробки інформації і проведення розрахунків призначені для підвищення оперативності управління і включають електронно-обчислювальні машини, розрахункові лінійки, таблиці, графіки, номограми.

Розвиток інформаційних технологій та їх інтенсивне впровадження у військовій сфері дає можливість при скороченні витрат на оборону не допустити зниження боєздатності збройних сил. Тому провідні країни світу питаннями підвищення боєздатності військ займаються ще 3 минулого століття, впроваджуючи новітні комп’ютерні технології в процеси управління, створюючи математичні моделі та алгоритми для автоматизації розрахунків. 31967 року США почали створювати автоматизовану систему управління вогнем і підрозділами «ТАКФАЙР», потім «AFATDS»; в 70-х роках Німеччина розробила систему «ADLER», яку на сьогодні удосконалила до «ADLER-II»; в 60-х роках СРСР розробив АСУВ «МАНЕВР». У Великобританії розроблена АСУВ «BATES», у Франції - «ATLAS».

Про ефективність застосування АСУВ говорить досвід ведення контрбатарейної боротьби багатонаціональних сил з 5-тисячним артилерійським угрупованням іракських військ при проведенні операції «Буря в пустелі». Комплекс контрбатарейної боротьби дивізії багатонаціональних сил складався з радіолокаційної станції «ФАЙРФАЙНДЕР», функціонально i інформаційно поєднаної за допомогою автоматизованої системи управління вогнем польової артилерії «ТАКФАЙР». Необхідна кількість РЛС забезпечувала своєчасне визначення координат батарей противника з максимальною похибкою 12 м, а їх підключення до АСУВ «ТАКФАЙР» - доведення в реальному масштабі часу даних до артилерійських підрозділів та відкриття вогню ще до моменту падіння снарядів противника.
У РФ на даний час впроваджується універсальна АСУВ для ствольної артилерії, мінометів і реактивних систем залпового вогню «Капустник-Б», яка є АСУВ нового покоління 3 високим рівнем «інтелектуальності» [6,7]. На думку російських фахівців, іiі застосування сумісно з модернізованими вогневими засобами, які оснащені АСУНВ «Успех», на 20-30\% підвищить загальну ефективність вогневого підрозділу. При цьому в 6 разів скоротиться час на підготовку вогню по цілях, на 20-30\% підвищиться точність вогню і на 30-40\% ймовірність ураження цілей. Крім того, в 3 рази підвищиться живучість підрозділу в умовах вогневого протиборства за рахунок своєчасної зміни вогневої позиції до завдання противником відповідного удару. При цьому зберігається управління підрозділом в ході його маневру на нову позицію. Значну роль при створенні АСУВ відіграє автоматизація САУ. Так, оснащення системою «УСПЕХ» САУ 2С19 «Мста-С» забезпечить іiі розгортання погарматно на довільній вогневій позиції і відкриття вогню з маршу за час не більше 3 хвилин, відкриття вогню на зайнятій вогневій позиції по неплановій цілі з моменту отримання цілевказівок за час не більше 10-15 секунд.

На озброєнні артилерійських підрозділів Сухопутних військ Збройних Сил України сьогодні знаходяться комплекси командирських машин управління 1B12, 1B17, які були створені ковровським НВО «Сигнал» наприкінці 1960-х - початку 1970-х років і прийняті на озброєння Радянської Армії в 1973 р. На сьогодні це комплекси з непрацюючими електронно-обчислювальними машинами та апаратурою прийому-передачі даних.

У відповідності з технічним описом і інструкцією з експлуатації виробу ЕОМ, що встановлено на 1В111, $1 \mathrm{~B} 16$ (АЗК-5, АЗК-7, АРК-1М), потрібне щомісячне напрацювання 30 годин на місяць. Але протягом останніх двадцяти років ні удосконаленням, ні підтриманням їх у працездатному стані ніхто не займався, планові технічні обслуговування не проводились, а якщо і проводились - то якість їх була невисокою. В результаті практично всі феритомагнітні ячейки плат довготривалої пам'яті розмагнічені. Крім того, підготовка операторів ЕОМ не проводилась. Тому всі розрахунки при підготовці даних для стрільби проводяться без використання штатних ЕОМ, що зводить процес автоматизації до безсистемності і призводить до втрати ефективності застосування артилерії.

Як показує досвід АТО, мобільні дії вогневих засобів НЗФ, коротка тривалість їх перебування на вогневій позиції (до 3-5 хвилин), а також ведення вогню 3 густонаселених районів вимагає від артилерійських підрозділів сил АТО значної точності та оперативності при відкритті вогню у відповідь. Це, в свою чергу, вимагає підвищення ефективної підготовки даних для 
стрільби. Тому для визначення пріоритетних напрямів розвитку вітчизняних АСУВ слід розглянути основні чинники, що впливають на ефективність стрільби артилерії.

В першу чергу на необхідність створення вітчизняних АСУВ вказує відсутність у військах цифрових засобів зв'язку для передачі інформації про об’єкти ураження і результати розрахунку даних від командирів артилерійських підрозділів до гармат. Незважаючи на прийняття на озброєння цифрових радіостанцій розробки ТОВ «Телекард-Прилад», розробки і серійного випуску підприємством ПАТ «Тернопільський радіозавод «Оріон» цифрової радіостанції з ППРЧ «Р-173 «Оріон» в артилерійських підрозділах такі радіостанції відсутні. Тому забезпечення оперативності обміну інформацією між посадовими особами артилерійських підрозділів потребує прийняття нестандартних рішень і підходів. Одним із таких рішень $\epsilon$ використання модемних пристроїв для передачі цифрових даних за допомогою аналогових радіостанцій. Такий підхід значно підвищить ефективність наявних засобів зв'язку і забезпечить можливість управління вогнем до впровадження в артилерійських частинах i підрозділах цифрового завадозахищеного зв'язку. Тому Державне підприємство «Оризон-Навігація» i ТОВ «НВП «Ефір-С» проводять роботи зі створення і відпрацювання модемних пристроїв для аналогових радіостанцій Р-159, Р-123М, Р-173.

На актуальність створення вітчизняних АСУВ вказує і досвід АТО. Під час проведення вогневих операцій в зоні бойових дій широкого використання в артилерійських підрозділах набули різного роду планшети, комунікатори, смартфони, ноутбуки з встановленим на них програмним забезпеченням для автоматизованого проведення розрахунку даних для стрільби. Найбільш вдалим серед таких засобів автоматизації слід вважати універсальний комплекс управління вогнем батарейного рівня UBLFDS (Universal Battery Level Fire Direction System) розробки компанії UDC (Ukranian Defense Consulting) [8]. Однак вказані засоби автоматизації розроблялись за індивідуальними проектами і не мають єдиної системної ідеології, тоді як всі розробки засобів автоматизації передових у військовому відношенні країн світу («Капустник-Б» - РФ, «ADLER-II» - Німеччина) ведуться як складові частини ACУВ артилерії тактичної ланки.

Для формування єдиної системної ідеології побудови засобів автоматизації і створення на їх основі вітчизняної АСУВ артилерії тактичної ланки розглянемо вплив основних чинників на точність і оперативність вогню АС.

Аналізуючи ваги похибок підготовки стрільби і управління вогнем, можна зробити висновок, що більшу частину похибок повної підготовки в дальності складають похибки балістичної та метеорологічної підготовки [5].
Балістична підготовка в дивізіоні (батареї) включає [3]: визначення відхилення початкової швидкості снарядів через знос каналу ствола гармати ${ }_{\Delta} V_{\text {огр }}$; визначення різнобою основних гармат батарей відносно контрольної гармати дивізіону та гармат батарей відносно основної ( $\left.\delta V_{o}\right)$; визначення сумарного відхилення початкової швидкості снарядів $\left({ }_{\Delta} V_{\text {oсум }}\right)$ для контрольної гармати дивізіону та основних гармат батарей; визначення температури зарядів; визначення балістичних характеристик боєприпасів; сортування та розподіл боєприпасів, які надійшли, між батареями (гарматами).

При стрільбі на дальності, що близькі до максимальних, сумарна похибка балістичної підготовки в дальності досягає 45-56\% всіх похибок (рис. 1) [9]. Вона складається 3 похибок визначення температури зарядів $E_{\Delta T z}$, похибок визначення відхилення початкової швидкості снарядів $E_{\Delta V o}$ та похибок врахування балістичних характеристик снаряда $E_{\text {АДсн }}$

$$
E_{x \sigma}=\sqrt{0,001 * \Delta X_{t z}^{2} * E_{\Delta T z}^{2}+\Delta X_{V_{o}}^{2} * E_{\Delta V o}^{2}+E_{\Delta Д с н}^{2}}
$$

Більш детальний аналіз фізичних процесів показує, що сумарне відхилення початкової швидкості снарядів містить в собі дві основні складові: відхилення початкової швидкості снарядів через знос каналу ствола гармати $\Delta \mathrm{V}_{\text {0гр }}$ (для мінометів приймається $\left.\Delta \mathrm{V}_{\text {огр }}=0\right)$ та відхилення початкової швидкості снарядів через властивості та особливості партії зарядів $\Delta \mathrm{V}_{\text {0зар. }}$

Відомо, що при зносі каналу ствола на межі його вибракування значення $\Delta \mathrm{V}_{\text {огр }}$ може досягати $-10 \% \mathrm{~V}_{0}$; значення $\Delta \mathrm{V}_{\text {0зар }}$ може змінюватися у межах від $2,5 \% \mathrm{~V}_{0}$ до $+2,5 \% \mathrm{~V}_{0}$. Для обов'язкового врахування при стрільбі $\Delta \mathrm{V}_{0 г \text { гр }}$ можна визначити за допомогою приладу заміру зарядної камори (ПЗК) і таблиць залежності відхилення початкової швидкості від збільшення довжини зарядної камори. Точність такого способу без уточнюючої поправки за допомогою артилерійської балістичної станції складає $0,4-0,7 \% \mathrm{~V}_{0}$, що не задовольняє вимогам повної підготовки стрільби.

Друга складова (відхилення початкової швидкості снарядів за властивостями та особливостями партії зарядів) повинна бути записана в ярликах, які вкладені в укупорку для пострілів. Точність ії визначення складає $0,3 \% \mathrm{~V}_{0}$. Але практика показує, що на складах боєприпасів ці ярлики в укупорці відсутні, а якщо і $\epsilon$, то за час зберігання властивості пороху в заряді давно вже не відповідають даним, що зазначені в ярлику. Без врахування другої складової точність визначення відхилення початкової швидкості може складати $0,81 \% \mathrm{~V}_{0}$ 
(для САУ 2С19 при стрільбі на максимальній даль-

ності така похибка буде складати приблизно 300 м).

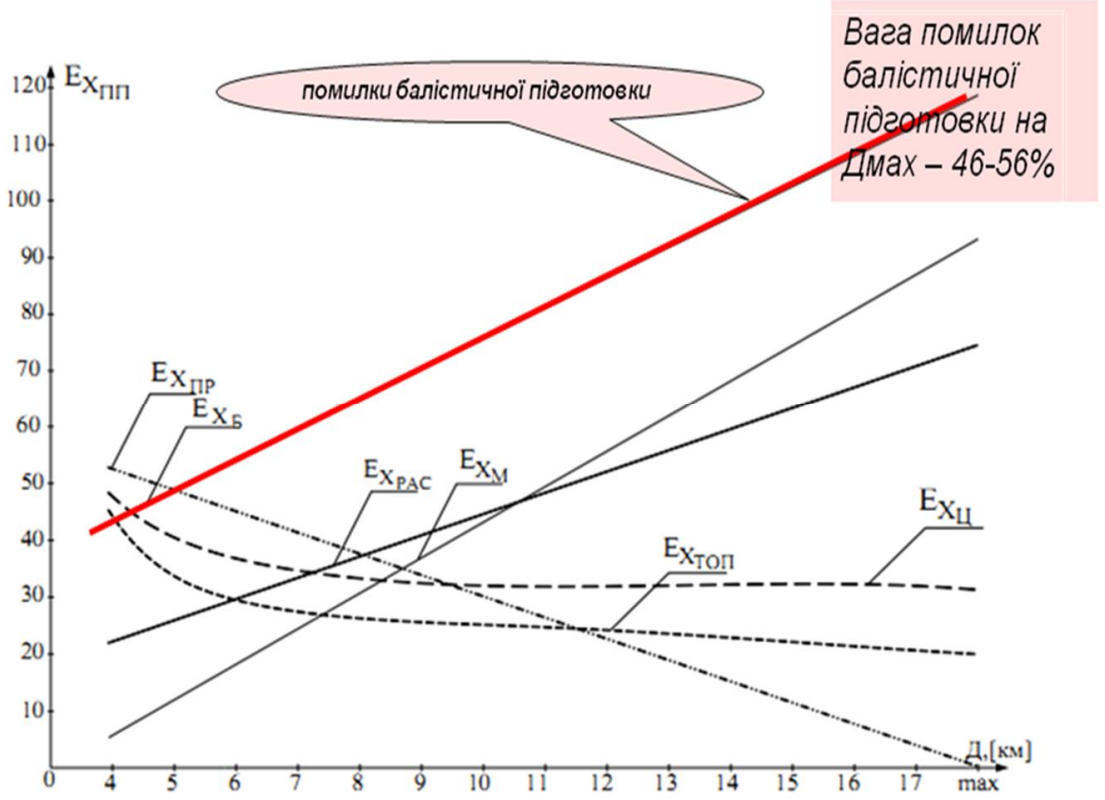

Рис. 1. Вага похибок повної підготовки при стрільбі 152-мм САУ 2СЗМ на повному заряді

Неврахування балістичних характеристик боєприпасів (конструкція снаряда, його маса, пофарбованість, наявність ковпачка підривника, матеріал i конструкція гільзи, наявність полум'ягасника у заряді, партія заряду) теж суттєво вплине на початкову швидкість та балістичний коефіцієнт снаряда i призведе до того, що стрільба на ураження без пристрілювання буде неефективною.

3 метою спрощення роботи командирів гармат Правила стрільби рекомендують підбирати до батареї гармати так, щоб їх різнобій не перевищував $0,5 \% \mathrm{~V}_{0}$ [3]. А керівництво з бойової роботи дозволяє не вводити гарматі індивідуальні поправки [10]:

- у рівень (приціл) та установку підривника (трубки): якщо різнобій гармати відносно основної не перевищує $0,5 \% \mathrm{~V}_{0}$; при лінійному розташуванні гармат на вогневій позиції; якщо різниця температури зарядів не перевищує $2{ }^{0} \mathrm{C}$; якщо перевищення гармати відносно основної не більше 0,001 Д $^{\text {}}$; якщо відхилення маси снарядів від нормальної не перевищує двох знаків; якщо невідповідність кута підвищення за прицілом і квадрантом не перевищує 2 тисячних;

- у кутомір на відхилення лінії прицілювання якщо відхилення не перевищує 3 поділки кутоміра.

За розрахунками для САУ 2С19 на дальності 20 км тільки неврахування таких допусків може привести до похибки в дальності: на різнобій 121 м; при лінійному розташуванні гармат і доворотах від основного напрямку стрільби 3-00 відповідно 12 м; на різницю температури зарядів - 56 м; перевищення гармати відносно основної - 20 м; якщо відхилення маси снарядів від нормальної не пере- вищує двох знаків (34 м); якщо невідповідність не перевищує 2 тисячних (42 м).

У сумі це може скласти 285 м. Тому при стрільбі ефективність батарейного залпу буде зведена до мінімуму.

Таким чином, неврахування всіх заходів балістичної підготовки може призвести до похибки по дальності 230 - 450 м в залежності від дальності стрільби. Наприклад, при стрільбі на дальність 20 км поправка в дальності на відхилення початкової швидкості снаряда на $1 \%$ для САУ 2С5 складає 232 м на повному заряді, для САУ 2С19 - 242 м на далекобійному заряді.

Крім того, внаслідок розігрівання стволів гармат у ході виконання вогневих завдань початкова швидкість і балістичний коефіцієнт снарядів можуть змінюватися, що значно впливає на точність стрільби. Для окремих АC і номерів зарядів значення похибок може досягати 1,8 \% топографічної дальності (при стрільбі на 20 км це буде складати 360 м) [5]. Таким чином, виникає необхідність більш точного визначення сумарного відхилення початкової швидкості снарядів.

Найбільш точним способом визначення сумарного відхилення початкової швидкості снарядів $\epsilon$ визначення його за допомогою артилерійської балістичної станції (АБС). Такий спосіб потребує мало часу і може проводитись під час стрільби. Однак, враховуючи те, що більшість АБС у військах вийшли 3 ладу, для підвищення ефективності, точності і своєчасності балістичної підготовки стрільби в Україні проводяться роботи з розробки перспективних АБС. Так, державним підприємством «Львівський науководослідний радіотехнічний інститут» (ЛНДРТІ) роз- 
роблена конструкторська документація і виготовлено тики АБС наведені в табл. 1.

дослідний зразок АБС (рис. 2). Технічні характерис-
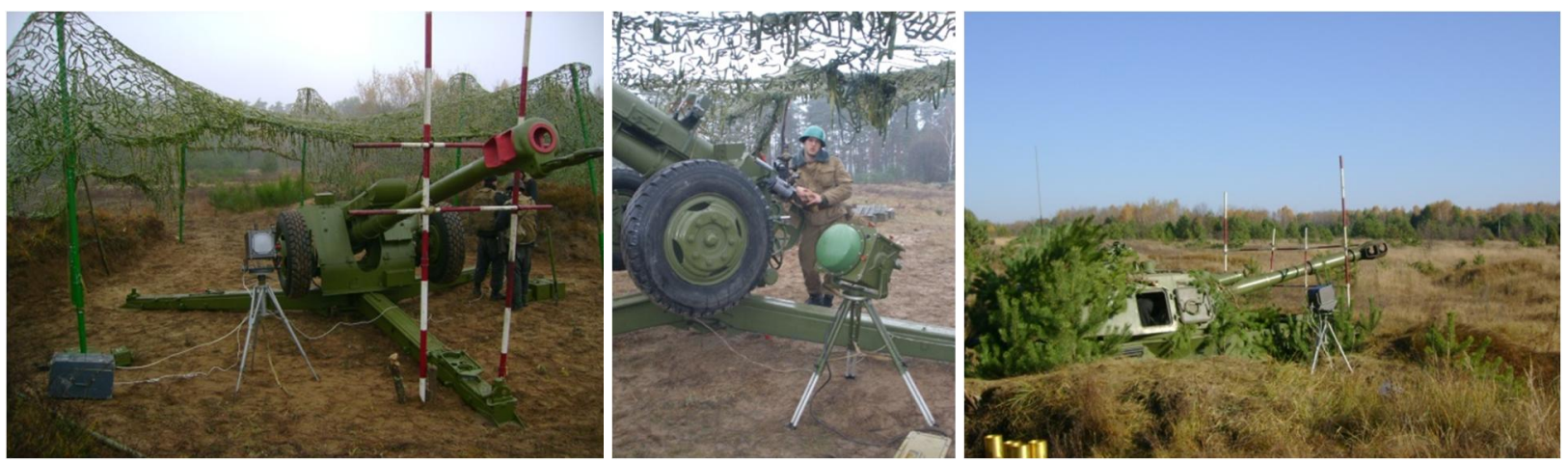

Рис. 2. Дослідний зразок АБС

Таблиия 1

Тактико-технічні характеристики АБС

\begin{tabular}{|l|l|}
\hline Параметр & Значення \\
\hline Дальність дії (калібр 122 - 152 мм) & $100-150 \mathrm{м}$ \\
\hline Відносні середньоквадратичні похибки вимірювань швидкості & $0,1 \%$ \\
\hline Діапазон випромінювання (довжина хвилі) & 60 ГГц (5) \\
\hline Вага, кг не більше & 15 \\
\hline Діапазон робочих температур & $-40+60{ }^{\circ} \mathrm{C}$ \\
\hline Первинне електроживлення & $11 \ldots 30 \mathrm{~B}$ \\
\hline Конструктивні особливості: засіб установки біля гармат & тринога \\
\hline
\end{tabular}

ТзОВ «НВП «ЕФІР-С» проведені теоретичні дослідження і створений експериментальний зразок портативної АБС, спряженої з автоматизованим формувачем установок для стрільби (АФУС) (рис. 3) [9]. Відпрацьовані засоби кріплення для монтажу АБС безпосередньо на противідкатних пристроях АС. За результатами стрільб визначені вібраційні навантаження місць встановлення і вимоги до конструктивних доробок зразка. Технічні характеристики, що очікуються отримати після доробки експеримента- льного зразка за результатами випробувань, зазначені в таблиці 2.

Аналіз даних таблиць 1, 2 показує, що реалізація технічних характеристик перспективних АБС значно підвищить ефективність застосування АС. Як приклад, при стрільбі на максимальні дальності 3 САУ 2С19 визначення сумарного відхилення початкової швидкості снаряда 3 похибкою $\leq 0,1 \% \mathrm{~V}_{\text {о }}$ забезпечить похибку в дальності $\leq 35$ м.

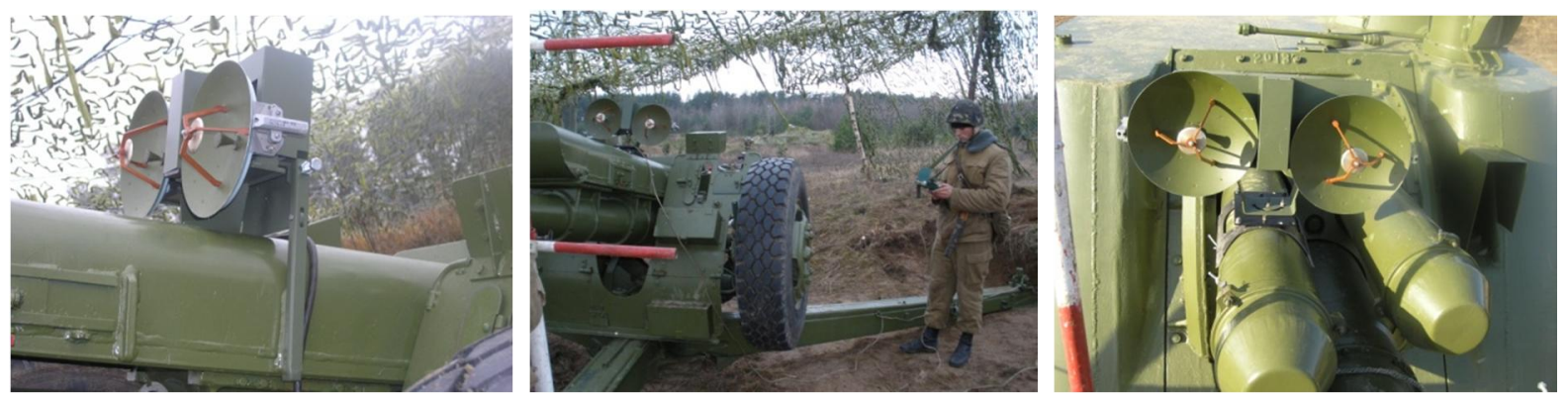

Рис. 3. Варіанти встановлення експериментального зразка портативної АБС на АС Д-30 і 2 С3М

Таблиия 2

Тактико-технічні характеристики портативної АБС

\begin{tabular}{|l|c|}
\hline Параметр & Значення \\
\hline Дальність дії (калібр 122 - 152 мм) & $1500-1800 \mathrm{M}$ \\
\hline Відносні середньоквадратичні похибки вимірювань швидкості & $0,1 \%$ \\
\hline Діапазон випромінювання (довжина хвилі) & 36 ГГц (8) \\
\hline Вага, кг не більше & 10 \\
\hline Діапазон робочих температур & $-40+60{ }^{\circ} \mathrm{C}$ \\
\hline Первинне електроживлення & $11 \ldots 30 \mathrm{~B}$ \\
\hline
\end{tabular}




\begin{tabular}{|l|c|}
\hline Параметр & Значення \\
\hline Конструктивні особливості кріплення на стволах гармат & $\begin{array}{c}\text {-кронштейн } \\
\text {-магнітна платформа }\end{array}$ \\
\hline
\end{tabular}

Розглянемо специфічні особливості метеорологічної підготовки стрільби.

При визначенні поправок на відхилення метеоумов від табличних величиною входу та визначення метеоелементів є висота траєкторії. При стрільбі на максимальну дальність для 2С19 вона складає 6910 м. При цьому снаряд пролітає кілька стандартних слоїв атмосфери (рис. 4) з різними значеннями метеоданих та різним їх впливом на снаряд в кожному шарі.

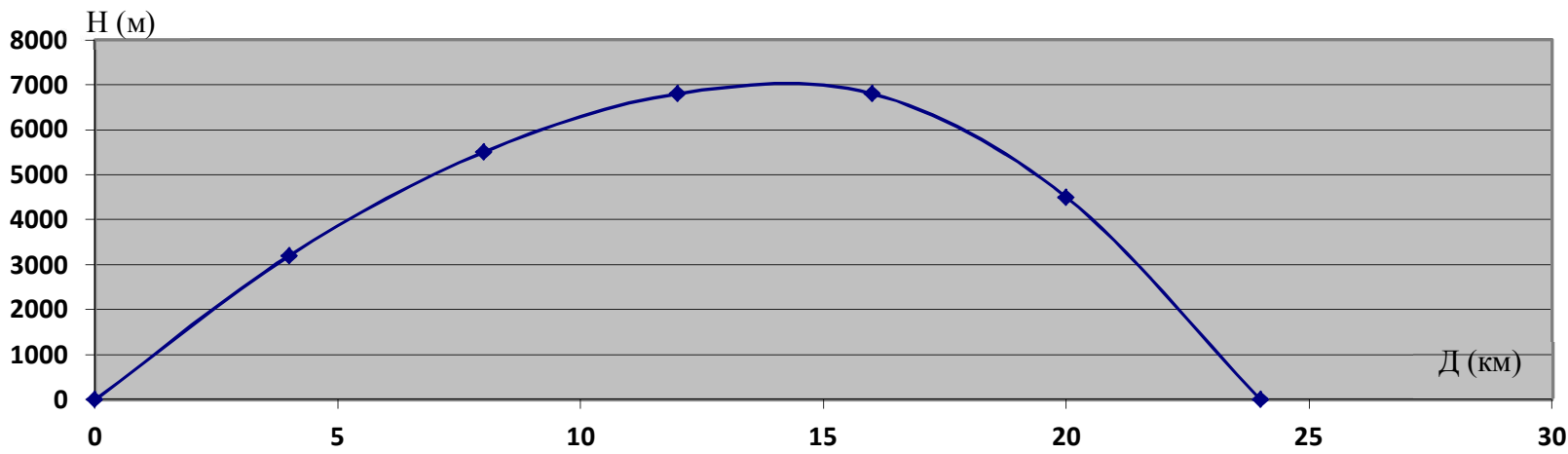

Рис. 4. Траєкторія польоту снаряда при стрільби з САУ 2 С19

Слід відмітити, що дані про стан атмосфери в різних шарах отримують лише за умов її зондування. Але на практиці, з причини великого об'єму розрахунків та відсутності автоматизації, значення метеоданих приймаються як середні по висоті траєкторії (середнє відхилення температури повітря в шарі атмосфери від поверхні землі до стандартної висоти, дирекційний кут і швидкість середнього вітру в тому ж шарі), що приводить до неточних розрахунків i похибки у 1-4 градусів за Цельсієм, при цьому похибки у визначенні напрямку вітру можуть складати 1-3 великі поділки кутоміра, а похибки визначення швидкості вітру у різних шарах $-1, \ldots, 4$ м/сек [5]. В сумі такі похибки можуть досягати по дальності до 270 м, в напрямку до 0-05, а повне неврахування відхилення метеоумов від табличних може привести до похибки у 2 км.

Таким чином, врахування параметрів атмосфери в кожному шарі при розрахунку поправок значно підвищить точність вогню АС. Однак це можливо тільки при наявності в складі АСУВ станцій метеорологічного зондування атмосфери. Створені науковим проектно-виробничим підприємством ТзОВ "Техприлад" [11] серійні зразки таких станцій надають підставу для створення ефективних вітчизняних АСУВ.

Відомо, що на ефективність стрільби артилерії (особливо при веденні контрбатарейної боротьби) суттєво впливає час, який витрачається на підготовку даних для стрільби. Тому розглянемо часові характеристики заходів повної підготовки стрільби.

Установки для стрільби у відповідності зі ст. 43 «Правил стрільби і управління вогнем» можуть визначатися за допомогою приладів або розрахунковим способом, але основним засобом визначення установок для стрільби є ЕОМ [3].

Досвід стрільб свідчить, що на визначення i введення усіх передбачених Правилами стрільби індивідуальних поправок гармат за заздалегідь розрахованою Таблицею індивідуальних поправок на вогневій позиції (ВП) витрачається від 0,5 до 1,5 хв. При повзводному чи розосередженому розташуванні гармат на ВП, коли необхідно додатково вводити поправки на інтервал, цей час збільшується. Такі затримки, пов'язані з визначенням індивідуальних поправок, суттєво стримують відкриття вогню, особливо при виконанні непланових вогневих завдань. Для порівняння можна зазначити, що на визначення вирахуваних установок по цілі за допомогою пристроїв та передачу їх на ВП засобами зв'язку витрачається в середньому кілька хвилин (таблиця 3, колонка 2), а на ввід даних в ЕОМ машини начальника штабу дивізіону і розрахунок установок при виконанні вогневих завдань на ураження спостережених цілей без пристрілювання із визначенням установок для стрільби за допомогою ЕОМ норми часу збільшуються на 30 секунд (таблиця 3, колонка 3) [4]. В крайньому правому стовпчику таблиці наведені дані результатів випробування експериментальних зразків перспективних засобів автоматизації (ПЗА). Такі зразки створюються вітчизняними підприємствами (ДП ЛНДРТІ, ДП «Оризон-Навігація», ТОВ «НВП «Ефір-С» та ін.) під керівництвом фахівців Академії сухопутних військ імені гетьмана Петра Сагайдачного. При створенні ПЗА, відповідного програмного забезпечення та спряження їх із засобами розвідки на це буде затрачено 
кілька секунд, що значно підвищить ефективність вогню АС. Проведені експериментальні дослідження експериментального зразка ПЗА зведені в четвертому стовпчику табл. 3 .

Табличяя 3

Час на підготовку даних

\begin{tabular}{|c|c|c|c|}
\hline Завдання & \begin{tabular}{|c|} 
Час на \\
підготовку \\
розрахунковим \\
способом \\
$($ хв $)$
\end{tabular} & $\begin{array}{c}\text { Час на } \\
\text { підготовку з } \\
\text { використанням } \\
\text { ЕОМ } \\
\text { (хв) }\end{array}$ & $\begin{array}{c}\text { Час на } \\
\text { підготовку з } \\
\text { використанням } \\
\text { ПЗА } \\
\text { (c) }\end{array}$ \\
\hline 1 & 2 & 3 & 4 \\
\hline \multicolumn{4}{|c|}{ НЗВ (координати вказуються в команді старшого начальника) } \\
\hline $\begin{array}{l}\text { Підготовка непланового НЗВ, РЗВ (по першому рубежу) } \\
\text { в складі бригади, БрАГ }\end{array}$ & 4,5 & 5 & $5-10$ \\
\hline Підготовка незапланованого НЗВ у складі дивізіону & 4 & 4,5 & $5-10$ \\
\hline Підготовка незапланованого НЗВ у складі батареї: & 3,5 & 4 & $5-10$ \\
\hline \multicolumn{4}{|c|}{ НЕЗАПЛАНОВАНА ЦІЛЬ (координати та розміри вказуються в команді старшого начальника) } \\
\hline Ураження незапланованої цілі: внакладку & 3,5 & 4 & $5-10$ \\
\hline $\begin{array}{l}\text { Ураження незапланованої цілі без пристрілювання } \\
\text { батареями внакладку (шкалою) в складі дивізіону }\end{array}$ & 3 & 3,5 & $5-10$ \\
\hline $\begin{array}{l}\text { Ураження незапланованої цілі без пристрілювання в } \\
\text { складі батареї }\end{array}$ & 3 & 3,5 & $5-10$ \\
\hline
\end{tabular}

Примітка. У таблиці вказаний робочий час без залучення штатних підрозділів згідно з Курсом підготовки артилерії 2013 на оцінку «добре» [4].

Особливістю ПЗА, що розробляються, є системний підхід до їх апаратно-програмної побудови. В першу чергу це стосується алгоритмів взаємодії структурних підрозділів і їх посадових осіб. Тому всі ланки цієї взаємодії повинні використовувати уніфікований протокол обміну інформацією $з$ мережевою адресацією абонентів. В якості апаратури термінальних пристроїв доцільно використовувати серійну апаратуру ДП «Оризон-Навігація»: СН-3210 3 новою модифікацією блока апаратури відображення і контролю та уніфіковані малогабаритні персональні комп’ютери “Карат” СН-4004. До складу цих пристроїв входять: приймач сигналів L1 GPS/SBAS C/A-код, L1 ГЛОНАСС СТ-код, L1 GALILEO/COMPASS, 32 універсальних канали, а також інтерфейси - UART, USB Host, USB OTG, Ethernet, WiFi/BT. Для ефективного використання в складі АСУВ в них необхідно реалізувати функції універсального балістичного калькулятора артилерійських підрозділів, картографічного засобу для навігаційного забезпечення топографічних підрозділів та ін.

Враховуючи сказане, фахівці Академії сухопутних військ імені гетьмана Петра Сагайдачного спільно 3 фахівцями ДП «Оризон-Навігація», ТзОВ «НВП «Ефір-С», ТзОВ «Техприлад» та ін. виконують роботи з інтеграції ПЗА в АСУВ, що проектується.
Враховуючи результати проведених досліджень, дані таблиці 3, можна зробити висновок, що розробка ПЗА і створення на їх основі вітчизняної АСУВ сьогодні $\epsilon$ найбільш пріоритетним напрямом практичної роботи науково-дослідних установ МО України і підприємств промисловості. Створення і застосування ПЗА значно підвищить точність і оперативність вогню АС і в цілому ефективність застосування артилерійських підрозділів.

Використовуючи напрацювання вітчизняних підприємств при створенні ПЗА, доцільно в подальшому розширити їх функції в напрямі оснащення машин управління та АC термінальними пристроями, які поєднані за допомогою засобів цифрового зв'язку із засобами розвідки, метеостанцією та об'єктовими засобами автоматизації: комплексованою системою навігації, АБС, АСУНВ та ін. Такий підхід дозволить в подальшому поєднати ПЗА в АСУВ тактичної ланки і на іiї основі створювати сучасні розвідувально-вогневі та розвідувально-ударні комплекси.

\section{Список літератури}

1. Бойовий статут Сухопутних військ. - Частина 2: Батальйон, рота. - К.: Видавництво «Варта», 2011. - $370 \mathrm{c}$.

2. Бойовий статут артилерії Сухопутних військ. Частина 2: Дивізіон, батарея, взвод, гармата. - К.: Видавниитво «Варта», 2011. - 370 c.

\section{Висновки}


3. Правила стрільби і управління вогнем наземної артилерії. Група, дивізіон, батарея, взвод, гармата. Київ - 2008. -304 c.

4. Курс підготовки артилерії Збройних Сил України. Артилерійська бригада, полк, бригадна артилерійська група, дивізіон, батарея, взвод. - Київ-2013. - 160 с.

5. Посібник по вивченню правил стрільби і управління вогнем наземної артилерії. Група, дивізіон, батарея, взвод, гармата. - Київ - 2008.

6. http://ru-artillery.livejournal.com/201348.html?thread $=2036612 \&$

7. http://bastion-karpenko.ru/kmn

8. http://i-802620.html.orotchenko. livejournal.com/
9. Грабчак B.I., Бударецький Ю.І., Прокопенко В.В. Джерела помилок та їх вплив на точність повної підготовки стрільби артилерії - Артиллерийское вооружение. 2011. - Bbin. 4

10. Керівниитво з бойової роботи вогневих підрозділів артилерії: Навчальний посібник. - СумДУ:Вид-во СумДУ, 2004.-267c.

11. http://techprulad.lviv.ua/index.php/ru/produkcia

Рецензент: д.т.н., с.н.с. А.М. Зубков, Академія сухопутних військ імені гетьмана Петра Сагайдачного, Львів.

\section{ВЛИЯНИЕ СРЕДСТВ АВТОМАТИЗАЦИИ УПРАВЛЕНИЯ ПОДРАЗДЕЛЕНИЯМИ И ОГНЕМ АРТИЛЛЕРИИ НА ЭФФЕКТИВНОСТЬ ЕЕ ПРИМЕНЕНИЯ}

П.П. Ткачук, Ю.И. Бударецкий, Ю.В. Щавинский, В.В. Прокопенко

Предлагаемая статья является попыткой анализа влияния наиболее важных факторов, которые влияют на точность и своевременность открытия огня артиллерийских систем. В современных военных вооружённых конфликтах это обуславливается необходимостью немедленного поражения объектов и иелей с высокой точностью. $B$ статье рассмотрено влияние средств автоматизации на точность и оперативность подготовки данных для стрельбы. Предложены пути программно-аппаратного построения средств автоматизачии, которые способствуют дальнейшему развитию автоматизированной системы управления огнём и артиллерийскими подразделениями, а также создание на её основании разведывательно-огневых и разведывательно-ударных комплексов.

Ключевые слова: автоматизированная система управления, АСУО, комплекс средств автоматизации, КСА, эффективность огня артиллерийских систем, точность подготовки данных для стрельбьл.

\section{INFLUENCE OF AUTOMATION CONTROL UNITS AND ARTILLERY FIRE ON THE EFFECTIVENESS OF ITS APPLICATION}

P. Tkachyk, Y. Budaretskiy, Y. Shchavinskiy, V. Prokopenko

Given article is an attempt to analyze the most important factors affecting accuracy and timing of artillery fire. In modern-day armed conflicts, artillery is expected to instantly strike given targets with high accuracy. This article reviews the influence of usage of automatic control systems on the accuracy and promptness of the artillery's firing data acquiring. The article also suggests number of ways of designing and implementing fire-control systems, which would contribute to further development of fire-control systems as well as reconnaissance-fire and reconnaissance-strike complexes based on the automatic control systems in review.

Key words: automated control system, ACS, complex means of automation, CMA, efficiency fire artillery systems, the accuracy of the data for firing. 